\title{
Pore Structure Characterization of Indiana Limestone and Pink Dolomite from Pore Network Reconstructions
}

\author{
Marina Freire-Gormaly ${ }^{1,2}$, Jonathan S. Ellis ${ }^{1}$, Heather L. MacLean ${ }^{2}$ and Aimy Bazylak ${ }^{1 *}$ \\ ${ }^{1}$ Thermofluids for Energy and Advanced Materials (TEAM) Laboratory, Department of Mechanical \& Industrial Engineering, \\ Faculty of Applied Science \& Engineering, University of Toronto, Toronto, Ontario - Canada \\ ${ }^{2}$ Department of Civil Engineering, Faculty of Applied Science \& Engineering, University of Toronto, Toronto, Ontario - Canada \\ e-mail:m.freire.gormaly@utoronto.ca - jon.ellis@utoronto.ca - heatherl.maclean@utoronto.ca-abazylak@mie.utoronto.ca \\ * Corresponding author
}

\begin{abstract}
Carbon sequestration in deep underground saline aquifers holds significant promise for reducing atmospheric carbon dioxide emissions $\left(\mathrm{CO}_{2}\right)$. However, challenges remain in predicting the long term migration of injected $\mathrm{CO}_{2}$. Addressing these challenges requires an understanding of pore-scale transport of $\mathrm{CO}_{2}$ within existing brine-filled geological reservoirs. Studies on the transport of fluids through geological porous media have predominantly focused on oil-bearing formations such as sandstone. However, few studies have considered pore-scale transport within limestone and other carbonate formations, which are found in potential storage sites. In this work, high-resolution micro-Computed Tomography (microCT) was used to obtain pore-scale structural information of two model carbonates: Indiana Limestone and Pink Dolomite. A modified watershed algorithm was applied to extract pore network from the reconstructed microCT volumetric images of rock samples and compile a list of pore-scale characteristics from the extracted networks. These include statistical distributions of pore size and radius, pore-pore separation, throat radius, and network coordination. Finally, invasion percolation algorithms were applied to determine saturation-pressure curves for the rock samples. The statistical distributions were comparable to literature values for the Indiana Limestone. This served as validation for the network extraction approach for Pink Dolomite, which has not been considered previously. Based on the connectivity and the pore-pore separation, formations such as Pink Dolomite may present suitable storage sites for carbon storage. The pore structural distributions and saturation curves obtained in this study can be used to inform core- and reservoir-scale modeling and experimental studies of sequestration feasibility.
\end{abstract}

Résumé - Caractérisation de la structure de pore de l'Indiana limestone de calcaire et de Pink dolomite provenant des reconstitutions de réseaux de pores - La séquestration du carbone dans les aquifères salins profonds souterrains est très prometteuse pour la réduction des émissions de dioxyde de carbone $\left(\mathrm{CO}_{2}\right)$ dans l'atmosphère. Cependant, des problèmes demeurent dans la prédiction de la migration à long terme du $\mathrm{CO}_{2}$ injecté. Relever ces défis nécessite une compréhension du transport de $\mathrm{CO}_{2}$ à l'échelle du pore dans des réservoirs géologiques existants remplis de saumure. Les études sur le transport des fluides en milieu poreux géologique ont principalement porté sur les formations oléagineuses telles que le grès. Cependant, peu d'études ont 
examiné les transports à l'échelle du pore dans le calcaire et d'autres formations carbonatées, qui se trouvent dans des sites de stockage potentiels. Dans ce travail, la micro-tomographie (microCT) à haute résolution a été utilisée pour obtenir de l'information structurale à l'échelle du pore de deux exemples de formations carbonatées : Indiana limestone et Pink dolomite. Un algorithme watershed a été appliqué pour extraire les réseaux de pores des images microCT volumétriques reconstruits des spécimens de roche et pour compiler une liste de caractéristiques pores des réseaux extraits. Il s'agit notamment de distributions statistiques de la taille et du rayon des pores, la séparation entres pores, le rayon des gorges, et la coordination du réseau. Enfin, des invasions de percolation ont été appliquées pour déterminer les courbes de saturation pression pour les exemples de roches. Les distributions statistiques sont comparables aux valeurs de la littérature pour l'Indiana limestone. Cela a servi de validation à l'approche d'extraction de réseau pour Pink dolomite, qui n'a pas été précédemment examinée. Basées sur la connectivité et la séparation entre pores, les formations telles que Pink dolomite peuvent présenter des sites de stockage appropriés pour le stockage du $\mathrm{CO}_{2}$. Les distributions de structure des pores et des courbes de saturation obtenue dans cette étude peuvent être utilisées pour informer et renseigner la modélisation à l'échelle du réservoir et les études expérimentales de faisabilité de a séquestration.

\section{INTRODUCTION}

Storage of carbon dioxide $\left(\mathrm{CO}_{2}\right)$ in underground geological formations is recognized as a promising method for reducing greenhouse gas emissions from concentrated sources, such as coal power plants or oil refineries [1]. This process entails the injection of $\mathrm{CO}_{2}$ into high-permeability, deep underground saline aquifers (greater than $800 \mathrm{~m}$ below surface [2]). Once underground, the upwards migration of the $\mathrm{CO}_{2}$ is arrested by low-permeability caprock formations (stratigraphic trapping), ensuring the perpetual sequestering of the stored $\mathrm{CO}_{2}$.

While the general mechanisms of sequestered $\mathrm{CO}_{2}$ transport underground is well characterized, challenges remain in estimating the storage capacity of geological formations and the long-term security of injected carbon within the porous rocks [3-5]. Reservoir scale analyses can estimate the macroscopic migration of carbon dioxide within the geologic formation [6]. However, these studies require estimates of pore-scale transport properties of the rock as inputs [7, 8]. Determination of transport parameters within pores requires detailed micro-scale studies of the detailed rock structure, which in turn can be used to calculate:

i) how $\mathrm{CO}_{2}$ will flood the rock and interact with in situ brine;

ii) the long-term stability of trapped carbon [9].

The pore- and micro-scale transport properties of sandstone reservoirs have been well characterized in the petrophysics literature [10-13], as sandstones contain a large portion of global petroleum reserves [10]. Recently, carbonate saline aquifers have been identified as suitable carbon dioxide sequestration sites due to their high porosity, effective stratigraphic trapping, and global abundance $[14,15]$. However, in contrast to sandstones, the complex microstructure of carbonates [16] requires a more in-depth investigation before their pore-scale transport can be known.

Limestone and dolomite form the main mineralogical components of carbonate saline aquifers [17]. Although bulk transport properties of many limestones [18] and dolomites [19] are known, a detailed examination of the microstructure of Pink Dolomite and Indiana Limestone is necessary to establish a robust methodology for characterizing carbonate geology and assessing potential storage sites in North America [3, 20].

A number of experimental techniques exist for microstructural characterization of carbonates [12, 21-31]. These include thin-section analysis [23], Scanning Electron Microscopy (SEM) [23, 24], focused ion beam-SEM [25], and mercury intrusion porosimetry [12, 21, 26, 27]. However, these techniques are destructive, so downstream or repeat measurements are impossible. Additionally, results obtained from multiple techniques must be averaged across many samples.

In contrast, $\mathrm{X}$-ray microCT, is a non-destructive technique for volumetric characterization, which has been used extensively to image porous materials in three-dimensions [28-30]. MicroCT facilitates subsequent analyses, including pore space extraction used to determine the characteristics of the pore microstructure. With this technique the porosity can be estimated directly from a binary volumetric image of the sample [22]. The volumetric images can be used directly in pore-scale flow simulations and compared to experimental studies.

The experimental techniques mentioned are required to determine the micro-structure of the rock that is inaccessible from a larger scale examination. The micro-structural volumetric images are used as inputs to modeling studies, which yield pore-scale transport parameters such as permeability. 
One modeling technique that has gained popularity in recent years is Pore Network Modeling (PNM), which involves a coarse-graining of a sample's void space so that it can be efficiently analyzed numerically [22, 32-37]. Techniques for extracting pore network models from digital microCT images were pioneered by Oren et al. [38].

A pore network model consists of a system of pores and connecting throats, whereby the detailed void space geometry obtained from microCT imaging is represented using simplified shapes [39]. Gharbi and Blunt [40] and Bijeljic et al. [41] performed PNM on a variety of sandstones and carbonates, and reported average pore-scale properties such as porosity, pore volume, radius and coordination number for one sample of each rock type explored. Youssef et al. [42] used microCT of carbonate and sandstone reservoir rocks to extract microporosity properties and to build a dual-porosity pore network model of the imaged rocks. Dual-porosity concerns for both Pink Dolomite and Indiana Limestone are considered in [43]; however, in this study we consider only the pore geometries accessible using microCT.

The present work expands on previous studies of the pore network structure of carbonates [40, 41] by performing detailed pore network extractions on multiple samples for two carbonates: Indiana Limestone and Pink Dolomite. Because Indiana Limestone has been considered previously, it can serve as a validation for the extraction and analysis methods used here. To the best of the authors' knowledge, this is the first comprehensive study of Pink Dolomite. Since dolomites form geologically under similar conditions to limestones, dolomites are of interest for $\mathrm{CO}_{2}$ capture and storage projects. Indiana Limestone and Pink Dolomite reasonably represent the porosity and permeability conditions identified for sequestration in the Alberta basin [20] and can be taken as representative model carbonates.

The pore extraction used in this study was a modified watershed algorithm [44], which built on existing studies of geologic materials [45-48] by enhancing the tessellation process to account for overlapping pores. Watershed methods were first used for geologic samples by Thompson et al. [49] and Sheppard et al. [50]. From the network extractions, full statistical distributions of pore size, radius and coordination number were reported, as well as throat radius and length. Full statistical distributions are required when constructing stochastic pore networks to generate a large simulation dataset. Finally, invasion percolation simulations were performed to explore the saturation behavior of the extracted networks. The geometry distributions presented here can be used as inputs for pore- and core-scale numerical studies for $\mathrm{CO}_{2}$ storage in carbonate formations and for upscaled geometric inputs for reservoir-scale simulations. This will provide a basis for determining optimal properties for storage in carbonate-based formations.

\section{METHODOLOGY}

The porous microstructure of two common carbonates, Indiana Limestone and Pink Dolomite, were examined. These rocks were selected as representative model carbonates for carbon storage activities in carbonate formations in the Alberta Basin of Western Canada, which is a proposed high intensity storage site [3]. Physical samples from this region could not be obtained due to property and licensing rights, so Indiana Limestone and Pink Dolomite were chosen to approximate porosity and permeability conditions identified for sequestration in the Alberta basin [20]. All core samples were obtained from Kocurek Industries (Caldwell, TX, USA). Their porosity and permeability as identified by the supplier are summarized in Table 1.

Attempts were made to verify the reported porosity using pycnometry; however, the small sample dimensions led to unreliable and inconsistent results. Similarly, a porosity estimate based on gravimetric techniques (weight and density calculations to estimate the void volume) was impossible because of the irregular dimensions of the samples. Each sample formed a cylinder with an irregular elliptical crosssection. Measurement errors in the evaluated volume led to large errors in the porosity. Attempts to machine a precise dimension were unsuccessful due to the low material hardness of both Indiana Limestone and Pink Dolomite, which crumbled when machined.

TABLE 1

Summary of the core properties obtained from Kocurek Industries indicating the permeability, and porosity of Indiana Limestone and Pink Dolomite

\begin{tabular}{c|c|c|c|c|c}
\hline Geologic material & Supplier & $\begin{array}{c}\text { Formation and } \\
\text { location }\end{array}$ & $\begin{array}{c}\text { Brine permeability } \\
\text { (milli-Darcy) }\end{array}$ & $\begin{array}{c}\text { Gas permeability } \\
\text { (milli-Darcy) }\end{array}$ & 200 \\
\hline Indiana Limestone & Kocurek Inc. & $\begin{array}{c}\text { Bedford, Indiana, } \\
\text { USA }\end{array}$ & 70 & 19 \\
\hline Pink Dolomite & Kocurek Inc. & $\begin{array}{c}\text { Edwards Plateau, } \\
\text { Texas, USA }\end{array}$ & 50 & 94 & 29 \\
\hline
\end{tabular}


TABLE 2

Summary of the sample sizes, voxel resolutions and dimensions of Indiana Limestone and Pink Dolomite. The voltage and currents reported were those used for collecting the microCT data

\begin{tabular}{|c|c|c|c|c|c|c|}
\hline & \multirow[b]{2}{*}{ Sample } & \multicolumn{2}{|c|}{ Approx. dimensions (mm) } & \multirow[b]{2}{*}{ Voltage $(\mathrm{kV})$} & \multirow[b]{2}{*}{ Current $(\mu \mathrm{A})$} & \multirow[b]{2}{*}{$\begin{array}{l}\text { Voxel resolution } \\
\qquad(\mu \mathrm{m})\end{array}$} \\
\hline & & $\begin{array}{l}\text { Cylinder, before } \\
\text { cropping } \\
\text { (diameter, height) }\end{array}$ & $\begin{array}{l}\text { Block, after } \\
\text { cropping }\end{array}$ & & & \\
\hline \multirow{4}{*}{$\begin{array}{c}\text { Indiana } \\
\text { Limestone }\end{array}$} & $\# 1$ & $6,8.5$ & $4.4 \times 3.6 \times 7.7$ & 120 & 90 & 11.07 \\
\hline & $\# 2$ & $6,6.5$ & $3.6 \times 4.3 \times 5.0$ & 135 & 60 & 8.3 \\
\hline & $\# 3$ & $6,9.0$ & $3.3 \times 3.0 \times 6.6$ & 135 & 60 & 8.3 \\
\hline & $\# 4$ & $6,8.5$ & $3.8 \times 3.9 \times 5.8$ & 135 & 60 & 8.3 \\
\hline \multirow{4}{*}{ Pink Dolomite } & $\# 1$ & $6,8.5$ & $4.5 \times 3.7 \times 6.0$ & 120 & 60 & 8.3 \\
\hline & $\# 2$ & $6,8.0$ & $4.2 \times 3.8 \times 5.3$ & 120 & 60 & 7.5 \\
\hline & $\# 3$ & $6,9.0$ & $3.7 \times 3.5 \times 6.3$ & 120 & 60 & 7.5 \\
\hline & $\# 4$ & $6,7.0$ & $3.4 \times 3.5 \times 4.5$ & 120 & 60 & 7.5 \\
\hline
\end{tabular}

\subsection{MicroCT}

Prior to scanning, each rock core was sectioned into four cylindrical samples $(1 \mathrm{~cm} \times 0.6 \varnothing \mathrm{cm})$ using a dremel. Four samples each of Indiana Limestone and Pink Dolomite were studied using microCT. The sample volumes were at least $66.5 \mathrm{~mm}^{3}$ for the Indiana Limestone, and $53.5 \mathrm{~mm}^{3}$ for the Pink Dolomite, which enabled detection of macro-pores within the samples, and could facilitate future investigations of permeability on the same samples [51].

MicroCT imaging was performed using a $G E$ Phoenix v|tome|x s equipped with a $180 \mathrm{kV} / 15 \mathrm{~W}$ high-power nanofocus X-ray tube (General Electric, CT, USA). Each sample was firmly affixed to the rotating table using hot-melt glue. To minimize beam hardening and ring artefacts, a $5 \mathrm{~mm}$ copper filter was used between the X-ray beam source and the sample. Any edge effects due to beam hardening were minimized during image processing, as described in Section 1.3, below. Voxel resolutions between $7.5-11.1 \mu \mathrm{m}^{3} /$ voxel were used ${ }^{1}$. Table 2 summarizes the settings, resolutions, and size of each scan. The microCT voltage and current were set to obtain the broadest normalized histogram, which guided the use of a $5 \mathrm{~mm}$ copper filter. Each sample scan took approximately three hours. The angle offset was set to zero. Each dataset contained 1440 images, obtained at $0.25^{\circ}$ intervals.

The datos $\mid \mathrm{x}$ image acquisition software system [52] was used to calibrate the device prior to scanning, and employed a pixel correction mask to minimize hotspots on the detector.

\footnotetext{
${ }^{1}$ A voxel is the smallest unit of a 3D image, compared to a pixel, the smallest unit of a $2 \mathrm{D}$ image.
}

The datos $\mid \mathrm{x}$ software was also used to reconstruct the scanned images following the scan.

\subsection{Mineral Characterization}

X-ray fluorescence spectroscopy was used to determine the mineral composition of the rock. This method provides the relative amount of each mineralogical component within the material $[53,54]$, and was conducted with a Philips PW2404 X-ray fluorescence spectrometer (Philips Corporation, Amsterdam, The Netherlands). The samples were individually ground to a fine powder using a ceramic mortar and pestle, then pelletized and placed in the sample holder for analysis. The mineral composition determines the surface tension and contact angle values used to calculate the capillary entry pressures for the invasion percolation, discussed below.

\subsection{Imaging Processing}

The volumetric images were processed in three stages: a) cropping, b) filtering, and c) binary thresholding, as outlined schematically in Figure 1. The image stacks were cropped (Tab. 2) to a cubic volume to facilitate analysis and ensure any edge damage due to cutting was removed from the image. The cropped image stacks were processed with a hybrid 3D median filter (4 voxel-sided cube; implemented in Fiji [55]) to remove residual noise and mitigate edge effects due to beam hardening [28-30]. The cropped and filtered microCT image stacks were then converted to 


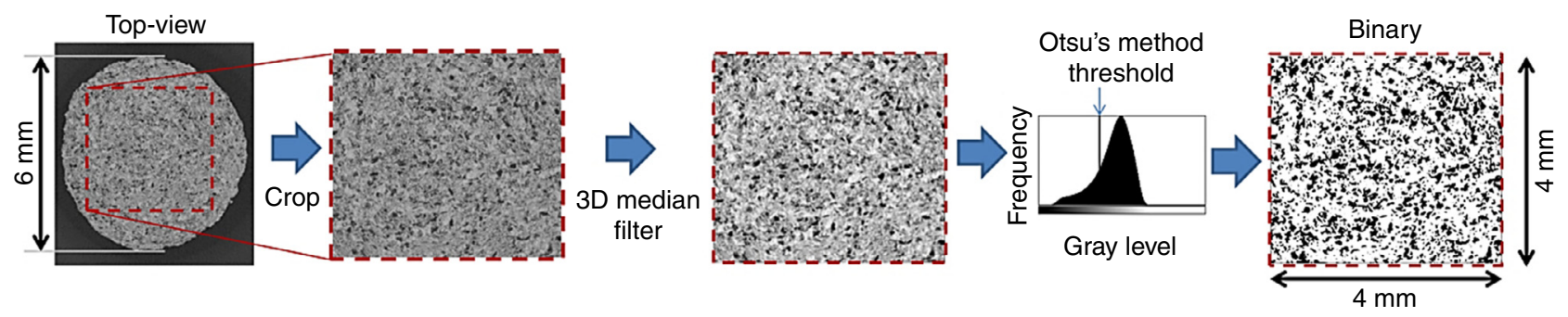

Figure 1

Schematic showing rock sample data processing and binarization methodology. Example sample shown is Pink Dolomite.

binary, black and white images using Otsu's thresholding method [56].

\subsection{Pore-Scale Properties}

To describe the microstructure of the pore space, the porosity, pore size, pore radius, throat radius, pore coordination number, and pore-to-pore distance were obtained. In this study, the following definitions are used:

- porosity is the void fraction of the sample, including connected and unconnected pores;

- pore size is the total digitally voxelized volume of each pore identified during pore network extraction;

- pore radius refers to the radius of the maximal inscribed sphere in each pore;

- throat radius is the radius of the minimal cross-sectional circle connecting two adjacent pores;

- coordination number identifies the number of adjacent pores connected to a given pore, and represents the connectivity of the pore space;

- pore-to-pore distance is the shortest void space path length between two pore centers, through the connecting throat.

\subsection{Pore Extraction}

Pore network models are simplified network diagrams representing the geometry and connectivity of the void space of a porous material. This method has been used extensively in geology to investigate the pore morphology of rock structures and to predict mesoscale fluid invasion patterns through the pore structure $[34,36,57,58]$.

In voxel-based pore extraction approaches, a maximal sphere is inscribed around each void voxel, wherein the sphere radius is the shortest distance between the voxel location and the solid wall [59]. A connected line normal to the solid wall of the largest such radii defines the skeleton of the topological network, for both pores and throats [60-64].
While these methods are effective in producing an accurate network model of the material, they are computationally expensive for the resolution available from 3D imaging techniques. Considerable improvements have been made in reducing computation time with the watershed algorithm [46, $48,65,66]$. This technique segments the void structure based on how water would fill the wetting volume [67], and then applies Voronoi tessellations [68] to locate the pore bodies within the total volume. A main advantage of the watershed algorithm is that it is computationally faster than maximal sphere techniques.

In a study by Hinebaugh and Bazylak [44], a novel pore network extraction technique was developed using the watershed algorithm, which builds on existing studies that use the watershed algorithm for geologic materials. In this enhanced version, the Voronoi tessellation was improved by accounting for overlapping pores, ensuring consistent throat lengths and trapped air phases were accounted for.

In this study, the enhanced watershed technique [44] was used to segment the void spaces of the Indiana Limestone and Pink Dolomite samples into a topological network of spherical pores (nodes) and cylindrical throats. From the extracted pore network, statistical parameters (pore size, pore radius, throat radius, pore coordination number, and pore-topore distance) describing the geological core samples were extracted and invasion studies were performed. The cropped images contained between 100 and 200 million voxels.

\subsection{Invasion Percolation}

Invasion percolation simulations were performed on each extracted network to determine saturation-capillary pressure curves for the core samples. The invasion percolations were performed using an algorithm developed in-house [16] based on the Washburn equation [69]. This describes the capillary pressure $P_{c}$ required to invade a pore:

$$
P_{c}=\frac{2 \gamma}{r} \cos \alpha
$$


where $\gamma$ is the surface tension, $r$ is the radius of the cylindrical throat, and $\alpha$ is the contact angle.

For the invasion percolation simulations, all external boundary pores were initially filled with mercury [22]. The pressure was incrementally increased until it overcame the entry pressure of an interface throat. Once this occurred, the volumes of the connected pore, and any subsequent connected pores and throats with lower capillary pressures, were filled. This process was repeated until all accessible pores were filled.

\section{RESULTS AND DISCUSSION}

Figure 2 shows sample 2D slices before processing and 3D representations of fully cropped and thresholded pore space for Indiana Limestone (a, c) and Pink Dolomite (b, d). As can be seen from a visual inspection of Figure 2, Indiana Limestone had a lower porosity, larger and more sparse pores, and higher pore coordination number than Pink Dolomite. Pink Dolomite's pores are more evenly

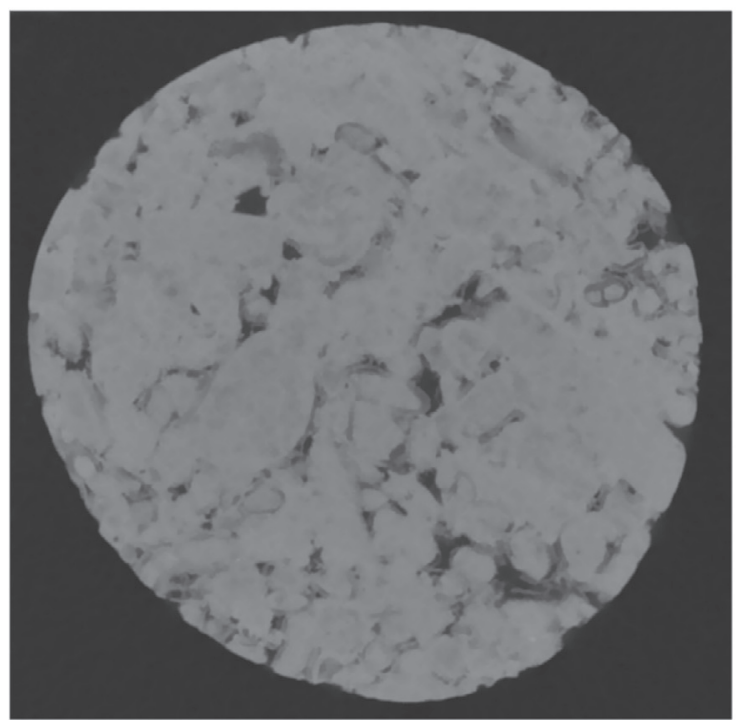

a)

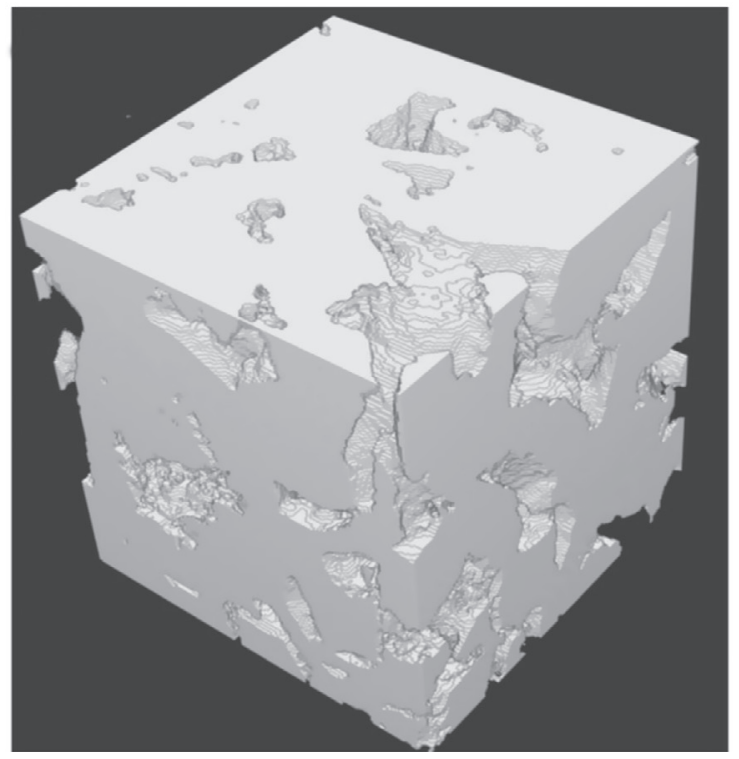

c)

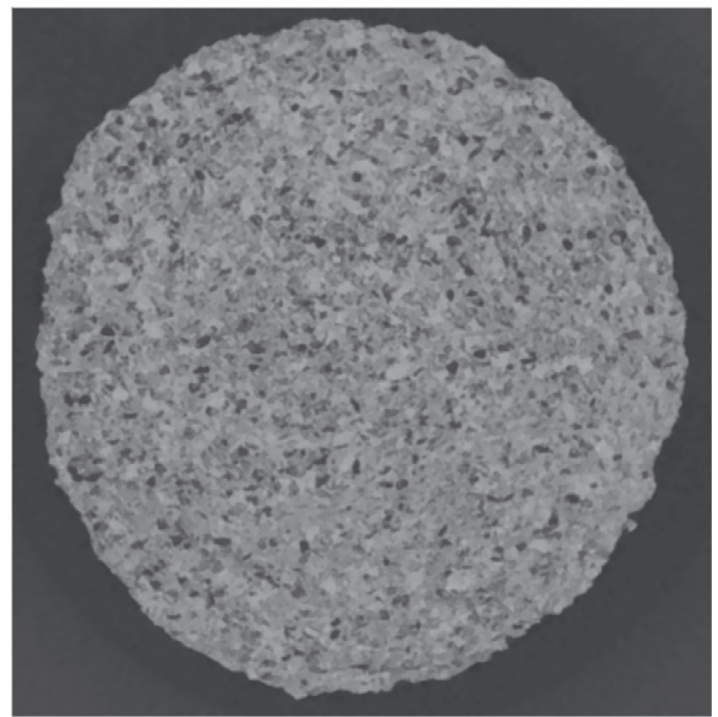

b)

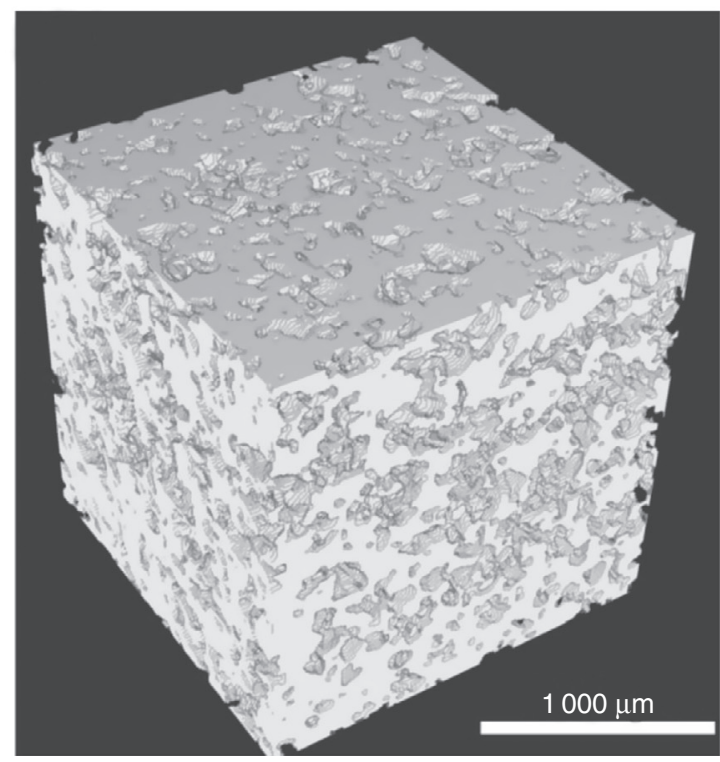

d)

Figure 2

MicroCT data cross-section of Indiana Limestone a); and Pink Dolomite b) at $8.3 \mu \mathrm{m}$ and $7.5 \mu \mathrm{m}$ resolution, respectively. The diameter of the cores in a) and b) are approximately $6 \mathrm{~mm}$. The 3D volumes of c) Indiana Limestone and d) Pink Dolomite show the microporosity and heterogeneity of the samples. The 3D images c, d) were generated using the 3D Viewer plugin in Fiji [55, 71]. 
TABLE 3

X-ray fluorescence results for the Indiana Limestone and Pink Dolomite samples

\begin{tabular}{c|c|c|c}
\hline \multicolumn{2}{c|}{ Indiana Limestone } & \multicolumn{2}{c}{ Pink Dolomite } \\
\hline $\begin{array}{c}\text { Chemical } \\
\text { compound }\end{array}$ & $\begin{array}{c}\text { Atomic weight } \\
(\%)\end{array}$ & $\begin{array}{c}\text { Chemical } \\
\text { compound }\end{array}$ & $\begin{array}{c}\text { Atomic weight } \\
(\%)\end{array}$ \\
\hline $\mathrm{CaCO}_{3}$ & 98.577 & $\mathrm{CaCO}_{3}$ & 99.391 \\
\hline $\mathrm{MgO}$ & 0.560 & $\mathrm{~K}_{2} \mathrm{O}$ & 0.140 \\
\hline $\mathrm{SiO}_{2}$ & 0.352 & $\mathrm{MgO}$ & 0.136 \\
\hline $\mathrm{FeO}^{2}$ & 0.143 & $\mathrm{Cl}$ & 0.104 \\
\hline $\mathrm{Al}_{2} \mathrm{O}_{3}$ & 0.117 & $\mathrm{SiO}_{2}$ & 0.091 \\
\hline $\mathrm{K}_{2} \mathrm{O}$ & 0.077 & $\mathrm{FeO}$ & 0.070 \\
\hline $\mathrm{Cl}$ & 0.064 & $\mathrm{Al}_{2} \mathrm{O}_{3}$ & 0.034 \\
\hline $\mathrm{S}$ & 0.048 & $\mathrm{Sr}$ & 0.016 \\
\hline $\mathrm{Na}_{2} \mathrm{O}$ & 0.031 & $\mathrm{~S}$ & 0.012 \\
\hline $\mathrm{Sr}$ & 0.021 & $\mathrm{P}_{2} \mathrm{O}_{5}$ & 0.007 \\
\hline $\mathrm{P}_{2} \mathrm{O}_{5}$ & 0.010 & - & - \\
\hline & & & \\
\hline
\end{tabular}

distributed throughout the material. This qualitative evaluation of Indiana Limestone is consistent with previous studies of this rock [40]. As stated above, this work represents the first micro-structural evaluation of Pink Dolomite. These comparisons are discussed in detail below.

\subsection{Mineral Composition}

The mineral compositions of Indiana Limestone and Pink Dolomite were $98.6 \%$ and $99.4 \%$, calcite $\left(\mathrm{CaCO}_{3}\right)$ by weight percent, respectively, determined using $\mathrm{X}$-ray fluorescence spectroscopy. Table 3 shows the detailed chemical composition of the rocks. The mineral composition of Indiana Limestone is consistent with literature values for bulk mineral composition [18]. To the best of our knowledge, this is the first report in the literature of the mineral structure for Pink Dolomite. Since both rocks were primarily calcite, a single contact angle of $140^{\circ}$ could be used in the invasion percolation studies presented below [23].

\subsection{Porosity}

For this and the following sections, Table 4 displays a comparison between the pore-scale properties of Indiana Limestone and Pink Dolomite, determined from the pore network extraction. Table 5 further compares the results obtained for Indiana Limestone in this study to similar studies.
TABLE 4

Pore structure distributions (mean and standard deviation) determined for Indiana Limestone and Pink Dolomite

\begin{tabular}{c|c|c}
\hline $\begin{array}{c}\text { Pore structure } \\
\text { features }\end{array}$ & Indiana Limestone & Pink Dolomite \\
\hline Porosity $(\%)$ & $12 \pm 2$ & $26 \pm 9$ \\
\hline Pore size $\left(\mu \mathrm{m}^{3}\right)$ & $(20 \pm 3) \times 10^{3}$ & $(7.3 \pm 0.2) \times 10^{3}$ \\
\hline Pore radius $(\mu \mathrm{m})$ & $31 \pm 2$ & $21 \pm 2$ \\
\hline \begin{tabular}{c} 
Throat radius $(\mu \mathrm{m})$ \\
\hline $\begin{array}{c}\text { Coordination } \\
\text { number }\end{array}$
\end{tabular} & $22 \pm 1$ & $13.6 \pm 0.4$ \\
\hline $\begin{array}{c}\text { Pore-to-pore } \\
\text { distance }(\mu \mathrm{m})\end{array}$ & $137 \pm 8$ & $9.2 \pm 0.1$ \\
\hline
\end{tabular}

TABLE 5

Pore space distributions of Indiana Limestone compared to literature values

\begin{tabular}{c|c|c}
\hline Parameter & This study & Gharbi and Blunt [40] \\
\hline \# of samples & 4 & 1 \\
\hline Porosity (\%) & $12 \pm 2$ & 13.05 \\
\hline $\begin{array}{c}\text { Number of voxels } \\
(\mu \mathrm{m})\end{array}$ & $\sim 450^{3}-530^{3}$ & $330^{3}$ \\
\hline $\begin{array}{c}\text { Voxel resolution } \\
\text { Physical sample } \\
\text { volume after } \\
\left.\text { cropping (mm }{ }^{3}\right)\end{array}$ & $8.3,11.1$ & 7.7 \\
\hline $\begin{array}{c}\text { Mean pore size } \\
\left(\mu m^{3}\right)\end{array}$ & $66.5-123.4$ & 16.41 \\
\hline $\begin{array}{c}\text { Mean pore radius } \\
(\mu \mathrm{m})\end{array}$ & $22 \pm 1$ & 10.17 \\
\hline $\begin{array}{c}\text { Mean pore } \\
\text { coordination number }\end{array}$ & $2.6 \pm 0.2$ & 2.97 \\
\hline $\begin{array}{c}\text { Number of pores } \\
\text { Number of throats }\end{array}$ & $9615-17960$ & 5653 \\
\hline $\begin{array}{c}\text { Num } \\
\text { (2) }\end{array}$ & $5603-11879$ & 839 \\
\hline
\end{tabular}

The porosity for the Indiana Limestone samples was $(12 \pm 2) \%$, which is lower than the sample provider's reported porosity of $19 \%$ by a significant margin. The precise explanation for the discrepancy between the provider's and our porosity measurements is unclear, and may be due to differences in the methodologies performed. However, the porosity found in this study matched closely with that reported by other researchers, $11 \%$ [41] and $13.05 \%$ [40].

The porosity of the Pink Dolomite samples was $(26 \pm 9) \%$. The standard deviation for the Pink Dolomite 


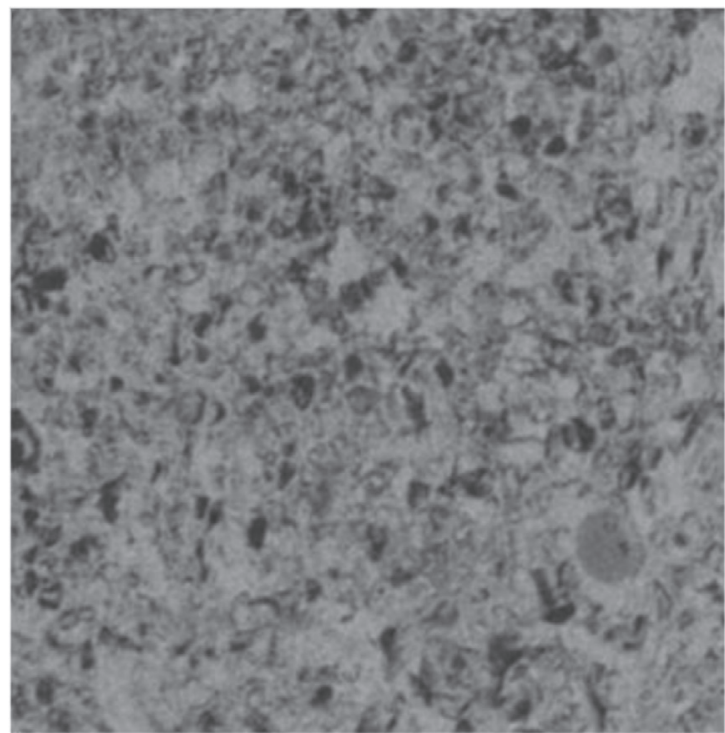

a)

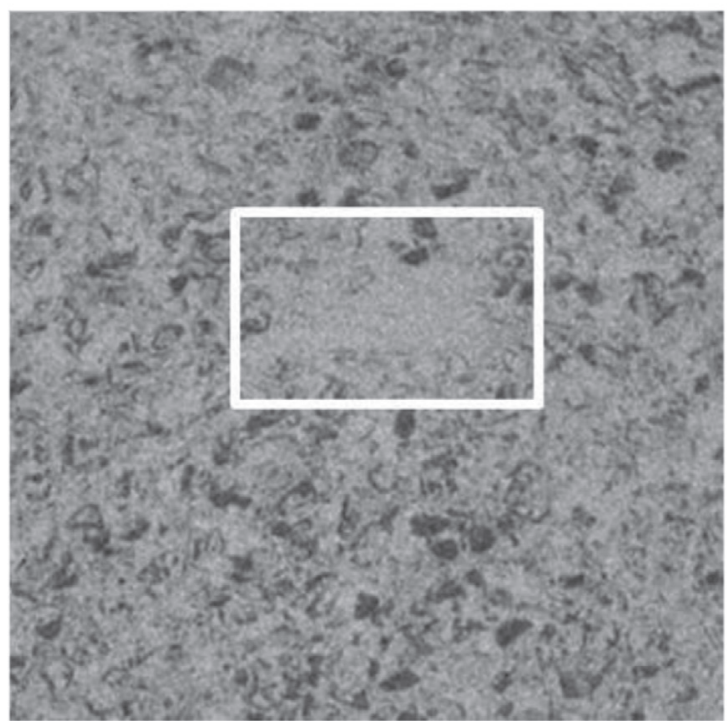

c)

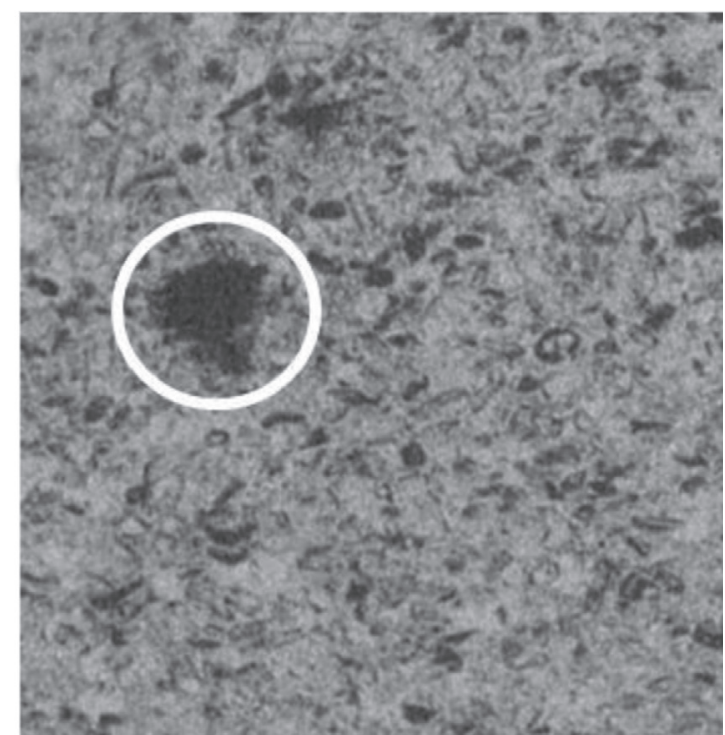

b)

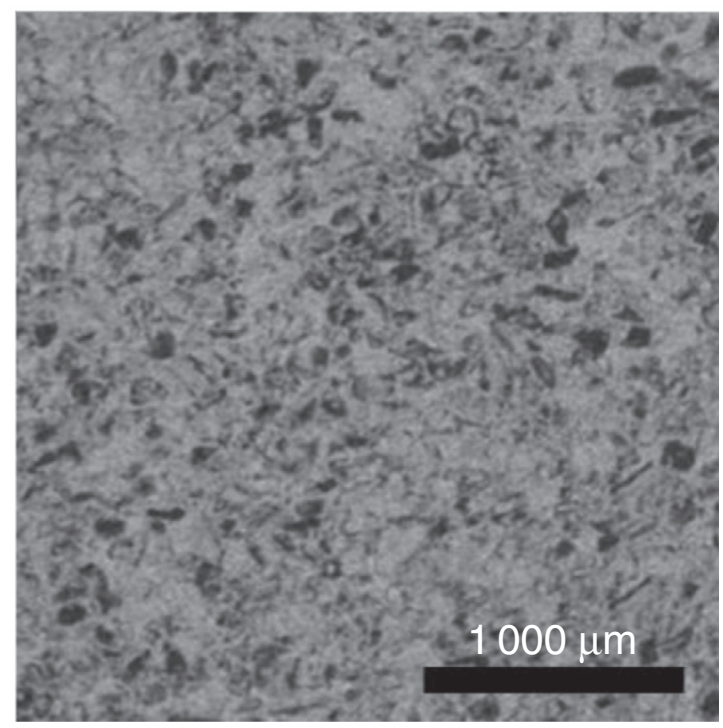

d)

Figure 3

Greyscale slices of the microCT image stacks show significant differences among the Pink Dolomite samples. Figures 3a-d are the Pink Dolomite samples $1-4$, respectively. In b), the large pore is circled in white. In c), a primarily solid region is highlighted with a white box. The length bar is applicable to Figure 3a-d.

porosity was large compared to Indiana Limestone. This can be attributed to the heterogeneity observed in the Pink Dolomite (Fig. 3). In Figure 3b, a large pore (circled feature) resulted in a higher porosity and in Figure $3 \mathrm{c}$, a region with high material fraction (box) led to a lower porosity. Large spatial heterogeneities within individual Pink Dolomite samples contributed to the observed variability in the porosity.

\subsection{Pore Size Distributions}

Figure 4 shows the pore size distributions for all pores and only the connected pores, for both rock types. For connected pores in each network, Indiana Limestone had a mean pore size of $(20 \pm 3) \times 10^{3} \mu^{3}$, while for Pink Dolomite, it was $(7.3 \pm 0.2) \times 10^{3} \mu \mathrm{m}^{3}$. A connected pore is one that is connected via a throat to another pore and 


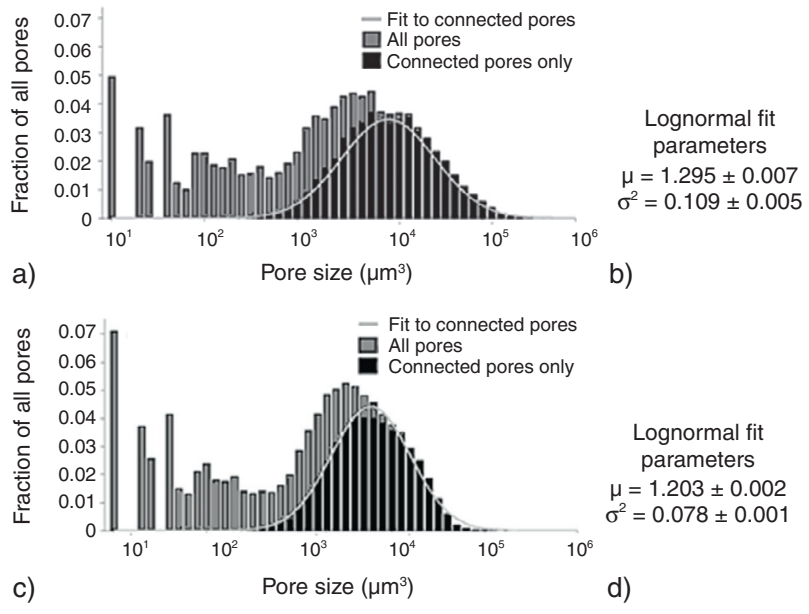

Figure 4

Pore size distributions for a) Indiana Limestone, and b) the associated lognormal fit to the distributions. Grey signifies all pores, and black represents the connected pores only. Pore size distribution for c) Pink Dolomite with d) the associated lognormal fit to the distributions. Note that the means and variances reported are for the lognormal distributions.

their distributions are presented in Section 2.5. In the extracted pore network models of both rock types, pores with a single voxel radius were exclusively unconnected and represented between $30-50 \%$ (count) of all pores. Unconnected pores in the extracted network are likely a result from resolution limits. In this study, the microCT resolution was sufficient to observe the macropores of the carbonates. However, since carbonates have pores well below the resolution of microCT, these could not be captured in the pore network model of the investigated samples. An analysis of that type would require sub-micron resolution imaging, so a complete evaluation of the unconnected pores is beyond the scope of this paper. The macropscopic parameters determined for these important carbonate samples provide the detail and statistical distributions for pore-to-core upscaling, and serve as a baseline for higher-resolution imaging studies.

\subsection{Pore and Throat Radius}

The mean pore radius of Indiana Limestone was $(31 \pm 2) \mu \mathrm{m}$, and for Pink Dolomite it was $(21 \pm 1) \mu \mathrm{m}$, as shown in Figure 5. There is more variability in pore radius between the Indiana Limestone samples, which is likely due to the larger and irregularly shaped pores for this rock. From a visual inspection, the Pink Dolomite pores are more regularly shaped.

The pore radii for the Indiana Limestone samples can be compared to other studies [40]. The extraction technique in
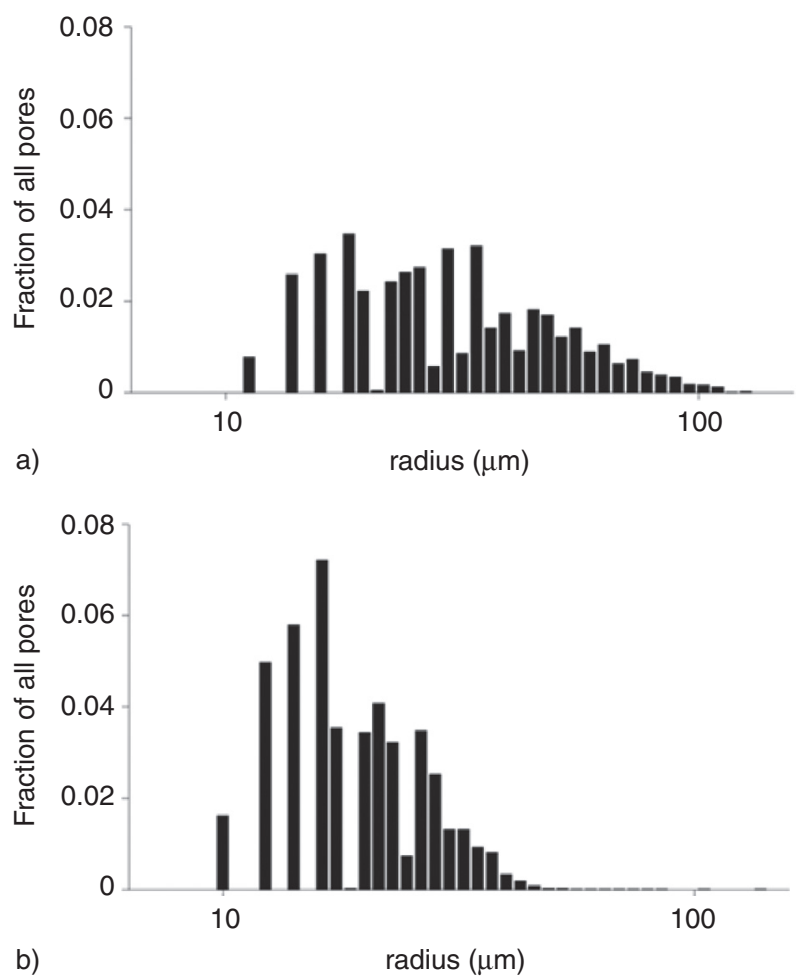

Figure 5

Pore radius distributions of the connected pores of the Indiana Limestone a) and Pink Dolomite b) samples.

this work found pore radii up to three times higher than previous studies (Tab. 5). A possible explanation for this deviation lies in the definition of a pore used by those authors. In that study [40], a pore was defined as the maximum circle inscribed within a triangle, and a throat as the connection between the pores [57]. In this study, the pore radius was defined by the maximally inscribed sphere, which can lead to larger radii. By comparison, Zhu et al. [31] performed thin-section analyses of Indiana Limestone and found pore radii in the range (35-50) $\mu \mathrm{m}$, which is in the range of the present study $\left(\tilde{r}_{\text {pore }}=31 \mu \mathrm{m}\right)$. The agreement between the thin-section analysis method [31] and this study demonstrates that the modified watershed technique can capture physical rock pore spaces.

The mean throat radius of Indiana Limestone was $(22 \pm 1) \mu \mathrm{m}$. The mean throat radius for Pink Dolomite was $(13.6 \pm 0.4) \mu \mathrm{m}$. Representative pore and throat interfaces for Indiana Limestone and Pink Dolomite, shown in Figure 6, illustrate that the pores and throats are indeed larger for Indiana Limestone than Pink Dolomite. As mentioned above, to the best of the author's knowledge, this is the first characterization of Pink Dolomite pore and throat radius distributions. 


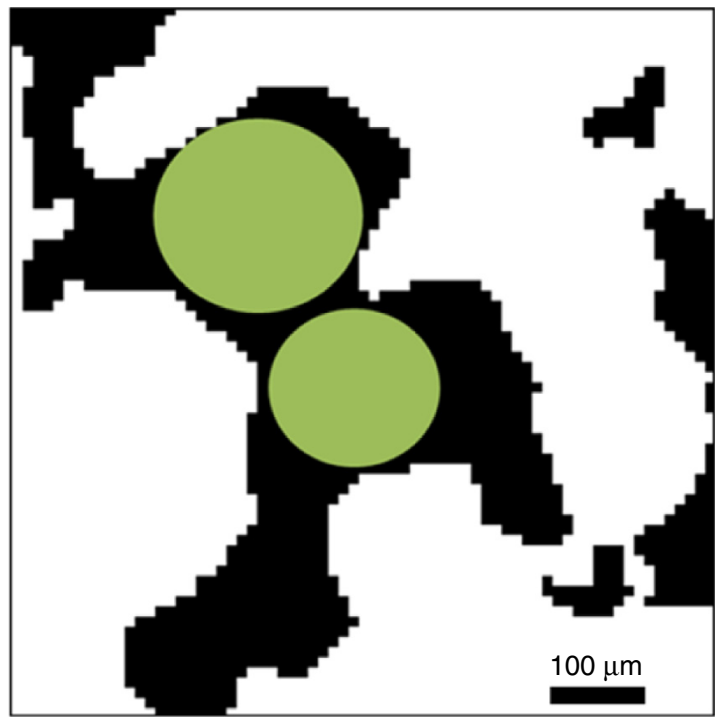

a)

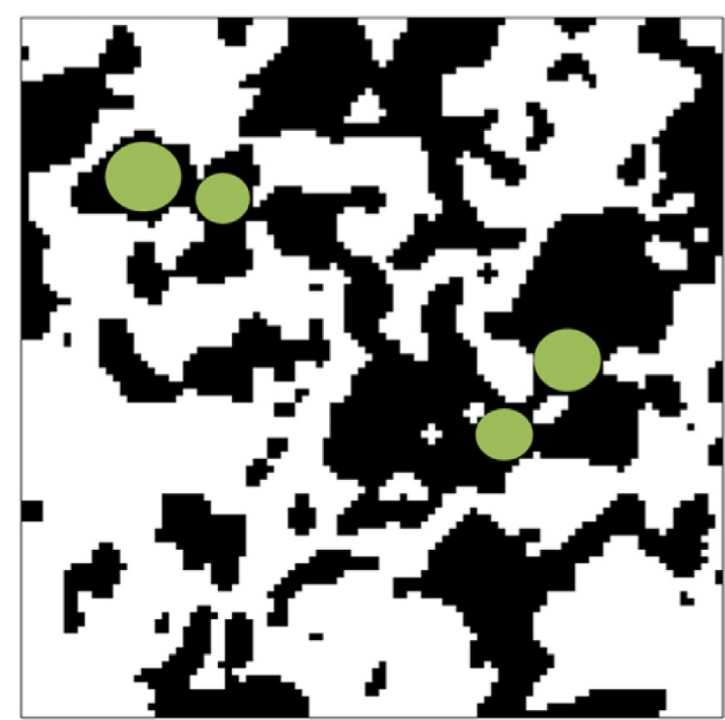

b)

Figure 6

Indiana Limestone a) and Pink Dolomite b) binary 2D microCT images of the pore space. Black is void space and white is solid. The green circles represent the maximal inscribed sphere (the 2D inscribed circles are presented for illustrative purposes only). The constrictions between green circles represent throats. The length bar in a) is applicable to both a) and b).

\subsection{Coordination Number}

The coordination number indicates the number of connections between each throat. Pore coordination number distributions are shown in Figure 7 and reveal that mean coordination of Indiana Limestone was $2.6 \pm 0.2$, for connected pores. This value is close to the literature value of 2.97 [40], as shown in Table 5. For the Pink Dolomite, the mean coordination number was determined to be $1.9 \pm 0.1$. The actual range of the coordination for Pink Dolomite, from 1 to 30, was larger than Indiana Limestone, which ranged from 1 to 20 .

\subsection{Pore-to-Pore Distance}

The pore-to-pore distance for Indiana Limestone was $(137 \pm 8) \mu \mathrm{m}$. For Pink Dolomite, the pore-to-pore distance was $(95 \pm 7) \mu \mathrm{m}$. This result is expected, since the Indiana Limestone pores were larger and more irregular than those of Pink Dolomite. Pore-to-pore distance is a suitable indicator of throat length, which could be used along with the throat radius to calculate the hydraulic conductance of throats. The hydraulic conductance could in turn be used to estimate the absolute and relative permeabilities of the sample; however, this is an involved exercise and is beyond the scope of this paper.

\subsection{Invasion Percolation}

Invasion percolation simulations were performed on one extracted network each of Indiana Limestone and Pink Dolomite. Figure 8 shows the saturation-capillary pressure curves for the pore networks. Capillary entry pressures were calculated from the Washburn equation (Eq. 1), with a contact angle of $140^{\circ}$ and surface tension of $0.480 \mathrm{~N} / \mathrm{m}$ used for a calcite and mercury interface [70], based on the mineral composition shown in Table 3.

From this analysis, this sample of Indiana Limestone has a lower barrier to filling than the Pink Dolomite, although both had similar final saturations, as a fraction of their total pore sizes. The final saturation is the highest saturation value on the capillary pressure versus volume saturation curves [16]. Multiphase saturations, residual trapping, and contrast saturation curves for different invading fluids could be included in future work, though these important aspects are outside of the current scope of work.

The Indiana Limestone curve (in dashed dark grey) has a value of $61 \%$, while the Pink Dolomite curve (in grey) has a value of $65 \%$ saturation. This indicates that both samples show a substantial fraction of their pore size accessible for injected carbon dioxide. The pressure limits at $0.69 \mathrm{kPa}$ for Pink Dolomite and $0.62 \mathrm{kPa}$ for Indiana Limestone were due to the voxel size and the minimum detectable throat radii. 


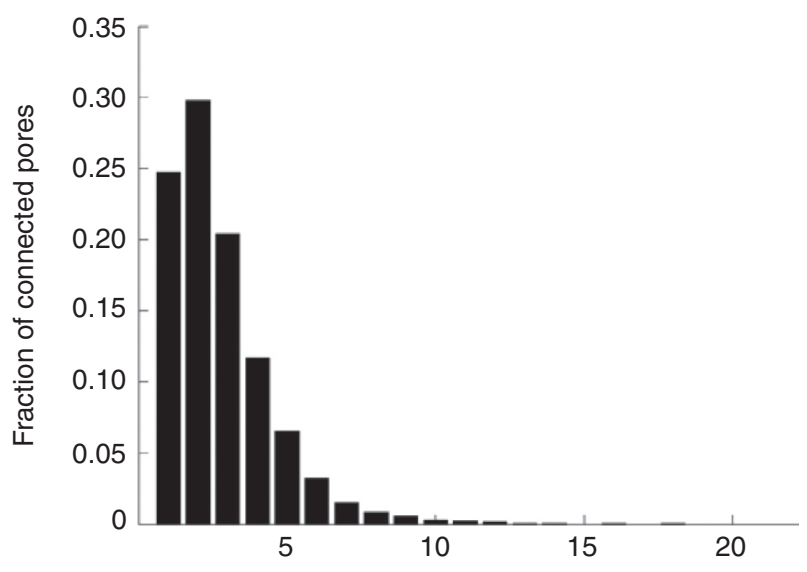

a)

Pore coordination number

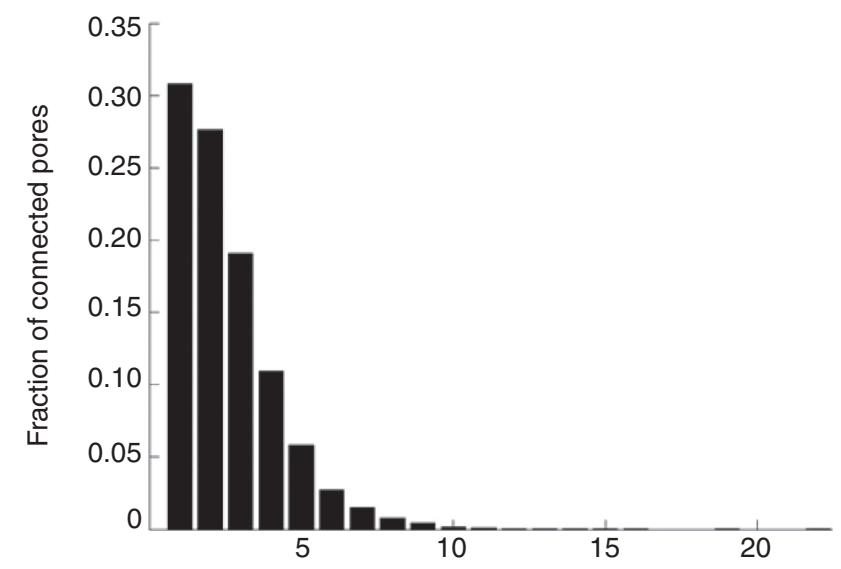

b)

Pore coordination number

Figure 7

Pore coordination number distributions for the Indiana Limestone a) and Pink Dolomite b) samples.

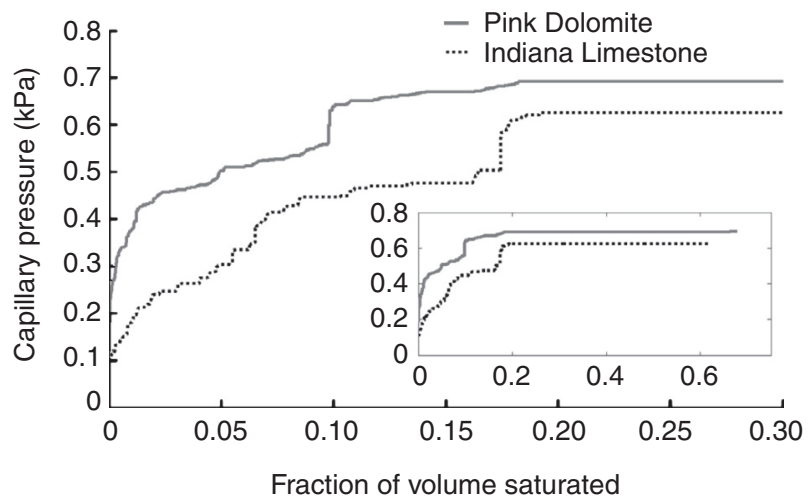

Figure 8

Capillary pressure versus saturation curves from invasion percolation results for Indiana Limestone (in dashed black) and Pink Dolomite (in grey). The figure highlights the increasing region, while the inset shows the full curve.

In future studies, higher resolution microCT will be performed in order to capture the minimum throat radii of the carbonates. As well, in future analyses, we will develop a comprehensive model to include both drainage and imbibition, which will allow us to explore $\mathrm{CO}_{2}$ trapping in carbonates.

\section{CONCLUSIONS}

In this study, the mesoscale structures and geometries of two carbonate rocks obtained by microCT imaging were evaluated to consider their suitability as potential carbon storage sites.
An enhanced watershed algorithm reported previously [44] was used to segment the void space of the rocks into topological pore network models. Using this method, series of pore-scale geometric parameter distributions for two model carbonate rock samples representative of possible carbon storage sites in Western Canada have been presented. Gaussian and lognormal statistical distributions (mean and standard deviations) for porosity, pore size and radii, throat radii, coordination number, and pore-to-pore distance have been determined for Indiana Limestone and Pink Dolomite.

The quantities presented here for the porosity (Indiana Limestone: 12\%; Pink Dolomite: $26 \%$ ) and the coordination number (Indiana Limestone: 2.6; Pink Dolomite: 1.9) compared well to reported literature values [40]. The pore radii values (Indiana Limestone: $31 \mu \mathrm{m}$; Pink Dolomite: $21 \mu \mathrm{m}$ ) were twice as large; however, this is likely due to the definition of a pore, and not to the imaging method or the extraction technique.

This study has also reported distributions for throat radii (Indiana Limestone: $22 \mu \mathrm{m}$; Pink Dolomite: $14 \mu \mathrm{m}$ ) and length (Indiana Limestone: $137 \mu \mathrm{m}$; Pink Dolomite: $95 \mu \mathrm{m}$ ), which have not been previously reported. To the best of our knowledge, this is also the first report of these geometric properties for Pink Dolomite. The primary contribution from this work is the full distribution of the microstructure characterizations. In future studies, the invasion percolation will be further developed to include multiphase flow, and the processes that would occur (such as mineralization) in a $\mathrm{CO}_{2}$ injection well.

These geometric considerations are all important in predicting the permeability and for determining which rock is more suitable for carbon storage. However, all these 
properties would need to be combined in a comprehensive model of flow in the porous rock. For example, coordination number, surface wettabilities, pore aspect ratio etc. would also be important considerations for modeling residual trapping, though it is outside the scope of this work.

Invasion percolation simulations were performed based on the invasion of mercury and simulated porosimetry. These simulations demonstrated that the sample of Indiana Limestone studied could have a lower capillary barrier $\left(P_{c} ;\right.$ Eq. 1) to filling than the Pink Dolomite sample, although both had similar final saturations as a fraction of their total pore sizes. Further analysis is required to determine which of these rock types is more suitable for $\mathrm{CO}_{2}$ injectivity. Instead, the model rock samples considered in this study are intended to provide a basis for developing a framework for imaging and pore network extraction relevant to carbon storage in deep carbonate saline aquifers.

Through this study, the groundwork has been established for the evaluation of these two types of carbonates. Statistical distributions of these properties could be used to generate larger stochastic networks for core scale simulations, and were determined for each property based on a mean and standard deviation.

\section{ACKNOWLEDGMENTS}

Financial support from the Natural Sciences and Engineering Research Council of Canada (NSERC), Canada Foundation for Innovation (CFI), Carbon Management Canada (CMC), the Ontario Ministry of Research and Innovation (Early Researcher Award), and the University of Toronto is gratefully acknowledged. Special thanks are owed to Dr. B. Tatone and Prof. G. Grasselli (Civil Engineering, University of Toronto) for their help with the microCT imaging, and Mr. G. Kretschmann (Earth Sciences, University of Toronto) for performing the XRF studies.

\section{REFERENCES}

1 Metz B., Davidson O., de Coninck H., Loos M., Meyer L. (eds) (2005) IPCC Special Report on Carbon Dioxide Capture and Storage, Cambridge University Press, p. 443.

2 Bachu S., Hawkes C., Lawton D., Pooladi-Darvish M., Perkins E. (2009) CCS site characterisation criteria, IEAG Greenhouse Gas R\&D Programme (IEAGHG), 2009/10, July 2009.

3 Bachu S. (2002) Sequestration of $\mathrm{CO}_{2}$ in geological media in response to climate change: road map for site selection using the transform of the geological space into the $\mathrm{CO}_{2}$ phase space, Energy Conversion and Management 43, 1, 87-102.

4 Nordbotten J.M., Celia M.A., Bachu S., Dahle H.K. (2005) Semianalytical Solution for $\mathrm{CO}_{2}$ Leakage through an Abandoned Well, Environmental Science \& Technology 39, 2, 602-611.
5 Shukla R., Ranjith P., Haque A., Choi X. (2010) A review of studies on $\mathrm{CO}_{2}$ sequestration and caprock integrity, Fuel 89, $10,2651-2664$.

6 Celia M., Nordbotten J., Dobossy M., Elliot T., Bandilla K. (2000) Modeling Options to Answer Practical Questions for $\mathrm{CO}_{2}$ Sequestration Operations, Analysis, pp. 1-19.

7 Bachu S. (2000) Sequestration of $\mathrm{CO}_{2}$ in geological media: criteria and approach for site selection in response to climate change, Energy Conversion and Management 41, 9, 953-970.

8 Ringrose P.S., Corbett P.W.M. (1994) Controls on two-phase fluid flow in heterogeneous sandstones, Geological Society, London, Special Publications 78, 1, 141-150.

9 Benson S.M., Cole D.R. (2008) $\mathrm{CO}_{2}$ Sequestration in Deep Sedimentary Formations, Elements 4, 5, 325-331.

10 Louis L., Baud P., Wong T.-F. (2007) Characterization of pore-space heterogeneity in sandstone by X-ray computed tomography, Geological Society, London, Special Publications 284, 1, 127-146.

11 Krevor S.C.M., Pini R., Li B., Benson S.M. (2011) Capillary heterogeneity trapping of $\mathrm{CO}_{2}$ in a sandstone rock at reservoir conditions, Geophysical Research Letters 38, 15, 1-5.

12 Tsakiroglou C.D., Payatakes A.C. (2000) Characterization of the pore structure of reservoir rocks with the aid of serial sectioning analysis, mercury porosimetry and network simulation, Advances in Water Resources 23, 7, 773-789.

13 Javadpour F. (2008) $\mathrm{CO}_{2}$ Injection in Geological Formations: Determining Macroscale Coefficients from Pore Scale Processes, Transport in Porous Media 79, 1, 87-105.

14 Roberts-Ashby T., Stewart M. (2012) Potential for carbon dioxide sequestration in the Lower Cretaceous Sunniland Formation within the Sunniland Trend of the South Florida Basin, US, International Journal of Greenhouse Gas Control 6, 113-125.

15 Thomas M., Stewart M., Trotz M., Cunningham J. (2012) Geochemical modeling of $\mathrm{CO}_{2}$ sequestration in deep, saline, dolomitic-limestone aquifers: Critical evaluation of thermodynamic sub-models, Chemical Geology 306-307, 29-39.

16 Bauer D., Youssef S., Fleury M., Bekri S., Rosenberg E., Vizika O. (2012) Improving the Estimations of Petrophysical Transport Behavior of Carbonate Rocks Using a Dual Pore Network Approach Combined with Computed Microtomography, Transport in Porous Media 94, 2, 505-524.

17 Manrique E., Gurfinkel M., Muci V. (2004) Enhanced Oil Recovery Field Experiences in Carbonate Reservoirs in the United States EOR in U.S. Carbonate Reservoirs, in 25th Annual Workshop \& Symposium Collaborative Project on Enhanced Oil Recovery International Energy Agency, pp. 1-32.

18 Owens J. (2009) Indiana Limestone Handbook, 22nd ed., Indiana Limestone Institute of America, Inc., p. 154.

19 Al-Awadi M., Clark W.J., Moore W.R., Herron M., Zhang T. (2009) Dolomite: Perspectives on a Perplexing Mineral, Oilfield Review 21, 3, 32-45.

20 Eisinger C., Jensen J. (2011) Reservoir Characterization for $\mathrm{CO}_{2}$ Sequestration: Assessing the Potential of the Devonian Carbonate Nisku Formation of Central Alberta, Oil \& Gas Science and Technology - Revue d'IFP Energies nouvelles 66, $1,47-65$.

21 Galaup S., Liu Y., Cerepi A. (2012) New integrated 2D-3D physical method to evaluate the porosity and microstructure of carbonate and dolomite porous system, Microporous and Mesoporous Materials 154, 175-186. 
22 De Boever E., Varloteaux C., Nader F.H., Foubert A., Békri S., Youssef S., Rosenberg E. (2012) Quantification and Prediction of the 3D Pore Network Evolution in Carbonate Reservoir Rocks, Oil \& Gas Science and Technology - Revue d'IFP Energies nouvelles 67, 1, 161-178.

23 Cerepi A. (2004) Geological control of electrical behaviour and prediction key of transport properties in sedimentary porous systems, Colloids and Surfaces A: Physicochemical and Engineering Aspects 241, 1-3, 281-298.

24 Goldstein J., Newbury D., Joy D., Lyman C., Echlin P., Lifshin E., Sawyer L., Michael J. (2003) Scanning Electron Microscopy and X-Ray Microanalysis, Kluwer Adacemic, Plenum Publishers, p. 688.

25 Bera B., Gunda N.S.K., Mitra S.K., Vick D. (2012) Characterization of nanometer-scale porosity in reservoir carbonate rock by focused ion beam-scanning electron microscopy, Microsc. Microanal. 18, 1, 171-178.

26 Hollis C., Vahrenkamp V., Tull S., Mookerjee A., Taberner C., Huang Y. (2010) Pore system characterisation in heterogeneous carbonates: An alternative approach to widely-used rock-typing methodologies, Marine and Petroleum Geology 27, 4, 772-793.

27 Ioannidis M., Chatzis I. (1993) A mixed-percolation model of capillary hysteresis and entrapment in mercury porosimetry, Journal of Colloid and Interface Science 161, 278-291.

28 Lindquist W. (2002) Quantitative analysis of three-dimensional $\mathrm{X}$-ray tomographic images, International Symposium on Optical Science 4503, 103-115.

29 Jerram D., Higgins M. (2007) 3D analysis of rock textures: Quantifying igneous microstructures, Elements 3, 4, 239-246.

30 Kalukin A.R., Van Geet M., Swennen R. (2000) Principal components analysis of multienergy X-ray computed tomography of mineral samples, IEEE Transactions on Nuclear Science 47, 5, 1729-1736.

31 Zhu W., Baud P., Wong T. (2010) Micromechanics of cataclastic pore collapse in limestone, Journal of Geophysical Research 115, B4, B04405.

32 Sufian A., Russell A.R. (2013) Microstructural pore changes and energy dissipation in Gosford sandstone during pre-failure loading using X-ray CT, International Journal of Rock Mechanics and Mining Sciences 57, 119-131.

33 Blunt M.J., Bijeljic B., Dong H., Gharbi O., Iglauer S., Mostaghimi P., Paluszny A., Pentland C. (2013) Pore-scale imaging and modelling, Advances in Water Resources 51, 197-216.

34 Raoof A., Hassanizadeh S.M. (2012) A new formulation for pore-network modeling of two-phase flow, Water Resources Research 48, 1, W01514.

35 Joekar-Niasar V., Hassanizadeh S.M. (2012) Analysis of Fundamentals of Two-Phase Flow in Porous Media Using Dynamic Pore-Network Models: A Review, Critical Reviews in Environmental Science and Technology 42, 18, 1895-1976.

36 Laroche C., Vizika O. (2005) Two-Phase Flow Properties Prediction from Small-Scale Data Using Pore-Network Modeling, Transport in Porous Media 61, 1, 77-91.

37 Hinebaugh J., Bazylak A. (2011) PEM Fuel Cell Gas Diffusion Layer Modelling of Pore Structure and Predicted Liquid Water Saturation, in American Society of Mechanical Engineers (ASME), 9th International Fuel Cell Science, Engineering and Technology Conference, Washington DC, pp. 1-8.
38 Oren P.E., Bakke S., Arntzen O.J. (1998) Extending Predictive Capabilities to Network Models, SPE Journal 3, 4, 324-336.

39 Thauvin F., Mohanty K. (1998) Network Modeling of NonDarcy Flow Through Porous Media, Transport in Porous Media 31, 1, 19-37.

40 Gharbi O., Blunt M.J. (2012) The impact of wettability and connectivity on relative permeability in carbonates: A pore network modeling analysis, Water Resources Research 48, 12, W12513.

41 Bijeljic B., Mostaghimi P., Blunt M.J. (2013) Insights into nonFickian solute transport in carbonates, Water Resources Research 49, 5, 2714-2728.

42 Youssef S., Bauer D., Han M., Bekri S., Rosenberg E., Fleury M., Vizika-Kavvadias O. (2008) Pore-Network Models Combined to High Resolution Micro-CT to Assess Petrophysical Properties of Homogenous and Heterogenous Rocks, in International Petroleum Technology Conference, 3-5 Dec., Kuala Lumpur, Malaysia, IPTC-12884.

43 Freire-Gormaly M., Ellis J.S., Bazylak A., MacLean H.L. (2015) Comparing thresholding techniques for quantifying the dual porosity of Indiana Limestone and Pink Dolomite, Microporous and Mesoporous Materials 207, 84-89.

44 Hinebaugh J., Bazylak A. (2010) Condensation in PEM Fuel Cell Gas Diffusion Layers: A Pore Network Modeling Approach, Journal of the Electrochemical Society 157, 10, B1382-B1390.

45 Chen Qing, Yang Xiaoli, Petriu E.M. (2004) Watershed segmentation for binary images with different distance transforms, Proceedings Second International Conference on Creating, Connecting and Collaborating through Computing, Proceedings the 3rd IEEE International Workshop on Haptic, Audio and Visual Environments and their Application, HAVE 2004, pp. 111-116.

46 Mkwelo S., De Jager G., Nicolls F. (2003) Watershedbased segmentation of rock scenes and proximity-based classification of watershed regions under uncontrolled lighting conditions, in Proceedings of 14th Annual Symposium of the Pattern Recognition Association of South Africa, (PRASA), pp. 107-112.

47 Zhou Y., Ren H.. (2012) Segmentation Method for Rock Particles Image Based on Improved Watershed Algorithm, 2012 International Conference on Computer Science and Service System (CSSS), 11-13 Aug., Nanjing, pp. 347-349.

48 Amankwah A., Aldrich C. (2010) Rock image segmentation using watershed with shape markers, 2010 IEEE 39th Applied Imagery Pattern Recognition Workshop (AIPR), pp. 1-7.

49 Thompson K.E., Willson C.S., Zhang W. (2006) Quantitative Computer Reconstruction of Particulate Materials from Microtomography Images, Powder Technology 163, 3, 169182.

50 Sheppard A.P., Sok R.M., Averdunk H., Robins V.B., Ghous A. (2006) Analysis of Rock Microstructure Using HighResolution X-Ray Tomography, SCA2006-26, International Symposium of the Society of Core Analyst, 12-16 Sept., Trondheim, Norway, Society of Core Analysts.

51 Mostaghimi P., Blunt M.J., Bijeljic B. (2012) Computations of Absolute Permeability on Micro-CT Images, Mathematical Geosciences 45, 1, 103-125.

52 Datos $\mid \mathrm{X}$ (Version 2.0) [Software] (2012) General Electric, Wunstorf, Germany. 
53 Landrot G., Ajo-Franklin J.B., Yang L., Cabrini S., Steefel C.I. (2012) Measurement of accessible reactive surface area in a sandstone, with application to $\mathrm{CO}_{2}$ mineralization, Chemical Geology 318-319, 7, 113-125.

54 Moon C.J., Whateley M.K.G., Evans A.M. (2006) Introduction to Mineral Exploration, Second Edition, Oxford, UK, Blackwell Publishing Ltd, pp. 499.

55 Schindelin J., Arganda-Carreras I., Frise E., Kaynig V., Longair M., Pietzsch T., Preibisch S., Rueden C., Saalfeld S., Schmid B., Tinevez J.-Y., White D.J., Hartenstein V., Eliceiri K., Tomancak P., Cardona A. (2012) Fiji: an opensource platform for biological-image analysis, Nature methods 9, 7, 676-682.

56 Otsu N. (1979) A Threshold Selection Method from Gray-Level Histograms, IEEE Transactions on System, Man, and Cybernetics 9, 1, 62-66.

57 Valvatne P.H., Blunt M.J. (2004) Predictive pore-scale modeling of two-phase flow in mixed wet media, Water Resources Research 40, 7, 1-21.

58 Ellis J.S., Bazylak A. (2013) Investigation of contact angle heterogeneity on $\mathrm{CO}_{2}$ saturation in brine-filled porous media using $3 \mathrm{D}$ pore network models, Energy Conversion and Management 68, 253-259.

59 Silin D., Patzek T.W. (2006) Pore space morphology analysis using maximal inscribed spheres, Physica A 371, 336-360.

60 Bhattad P., Willson C., Thompson K. (2011) Effect of Network Structure on Characterization and Flow Modeling Using X-ray Micro-Tomography Images of Granular and Fibrous Porous Media, Transport in Porous Media 90, 363-392.

61 Dong H., Blunt M. (2009) Pore-network extraction from micro-computerized-tomography images, Physical Review E 80, 3, 1-11.

62 Al-Kharusi A.S., Blunt M.J. (2007) Network extraction from sandstone and carbonate pore space images, Journal of Petroleum Science and Engineering 56, 4, 219-231.
63 Jiang Z., Dijke M.I.J., Wu K., Couples G.D., Sorbie K.S., Ma J. (2011) Stochastic Pore Network Generation from 3D Rock Images, Transport in Porous Media 94, 2, 571-593.

64 Silin D., Tomutsa L., Benson S.M., Patzek T.W. (2010) Microtomography and Pore-Scale Modeling of Two-Phase Fluid Distribution, Transport in Porous Media 86, 2, 495-515.

65 Petriu E.M. (2004) Watershed segmentation for binary images with different distance transforms, Proceedings Second International Conference on Creating, Connecting and Collaborating through Computing, pp. 111-116.

66 Zhou Y., Ren H. (2012) Segmentation Method for Rock Particles Image Based on Improved Watershed Algorithm, 2012, International Conference on Computer Science and Service System, pp. 347-349.

67 Roerdink J.B.T.M., Meijster A. (2001) The Watershed Transform: Definitions, Algorithms and Parallelization Strategies, Fundamenta Informaticae 41, 187-228.

68 Alshibli K.A., El-Saidany H.A. (2001) Quantifying Void Ratio in Granular Materials Using Voronoi Tessellation, Journal of Computing in Civil Engineering 15, 3, 232-238.

69 Washburn E.W. (1921) Note on a method of determining the distribution of pore sizes in a porous material, Proceedings of the National Academy of Sciences 7, 115-116.

70 Wilkinson D., Willemsen J. (1983) Invasion percolation: a new form of percolation theory, Journal of Physics A: Mathematical 16, 3365-3376.

71 Schmid B., Schindelin J., Cardona A., Longair M., Heisenberg M. (2010) A high-level 3D visualization API for Java and ImageJ, BMC Bioinformatics 11, 274.

\author{
Manuscript submitted in March 2014 \\ Manuscript accepted in February 2015 \\ Published online in August 2015
}

Cite this article as: M. Freire-Gormaly, J.S. Ellis, H.L. MacLean and A. Bazylak (2016). Pore Structure Characterization of Indiana Limestone and Pink Dolomite from Pore Network Reconstructions, Oil Gas Sci. Technol 71, 33. 